\title{
Supply Chain Gaps In After Sales Services with Special Focus on Consumer Durables: A Study
}

\author{
Harish Kumar S. Purohit ${ }^{1}$ and Nitin Joshi ${ }^{2}$ \\ ${ }^{1} P T V A$ 's Institute of Management (Affiliated to \\ University of Mumbai), Maharashtra, India \\ ${ }^{2} D r$. V. N. Bedekar Institute of Management Studies (Affiliated to \\ University of Mumbai), Maharashtra, India
}

\section{ABSTRACT}

After-sales service business growth has been on rise and it has become one of the most important drivers of business revenues. Improvement in the quality of service leads to enhanced customer satisfaction, which, ultimately increases the sales of a newly introduced product. With the growing trend of outsourcing and cut-throat competition in the manufacturing industry, quality after-sales service has become an integral way of enhancing customer value. However, when it comes to after sales services not much research work has been done. Technology has moved into every part of the business but yet to fully embrace after sales services. Similarly supply chain improvement have been seen on many products but a lot of work has to be done in improving the supply chain efficiencies in the after sales services domain which is a big revenue source for manufacturers. Efforts have been made by the researchers to find out the gaps in the supply chain in the after sales services domain especially in the consumer durable product and appliances. The output of the research would help the professionals in after sales service industry to reduce the gaps by deploying process improvements tools or by using technology to bridge the gap

\section{KEY WORDS: SERVICES SUPPLY CHAIN, AFTER SALES SERVICES, SERVICES GAPS IN AFTER SALES SERVICES.}

\section{INTRODUCTION}

We are in an era where services sector is dominating and most of the contribution to our GDP is coming out of services sector. Services industry works mostly on the parameters of trust, experience and reliability. It has been shared earlier by many researchers that gaps in the services appear as one of the components which is stated by Servqual model. Trust and loyalty can be developed only when experiences with the service are

\section{ARTICLE INFORMATION}

Received 13th Oct 2020 Accepted after revision 28th Dec 2020 Print ISSN: 0974-6455 Online ISSN: 2321-4007 CODEN: BBRCBA

Thomson Reuters ISI Web of Science Clarivate Analytics USA and Crossref Indexed Journal

\section{Clarivate
Analytics}

NAAS Journal Score 2020 (4.31)

A Society of Science and Nature Publication,

Bhopal India 2020. All rights reserved.

Online Contents Available at: http//www.bbrc.in/

Doi: http://dx.doi.org/10.21786/bbrc/13.15/61 good and services provider is in a position to establish relation with the customer. Communication gap being one of the root causes of all the problems, instead of focusing on reducing this major gap, it is often assumed that once the technical systems are properly established, they will take care of the harmonial relationships within as well as between organizations in a supply chain. However, the fact remains that relationship management is very crucial and still often neglected in supply chain management. Relationship management along with process management becomes very important ingredient for effective supply chain management. This has the capacity of building confidence in the other members of the ecosystem. It is extremely difficult to deliver results without positive interpersonal relationships.

Collaboration with regards to supply chain management has the potential of bringing together capabilities and investments of partners in time, infrastructure, money, and intellectual capital that can enable organizations

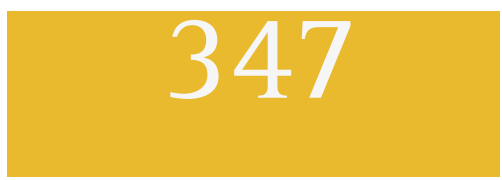


create that value which standalone organization may find it extremely difficult to achieve. This value creation by creating of service attitude which actually becomes a big differentiator to achieve long term sustainable competitive advantage for the organization. Continuous development in the organization with regards to services providers and relationship management in services ecosystem becomes the most important parameter for generating revenues and also for competitive advantage not only for self but also for partner organization. In the era of globalization where we face cut throat competition, ability to deliver unique value purely depends on productive collaboration. Some of the other vital ingredients to create value in the services supply chain include application of joint innovative programs, quality processes, objective oriented frame works, focus on new technology and services attitude.

Literature Review: Services sector has a huge competition and hence gaps in the supply chain should be eliminated to the extent possible. A lot of authors have their view with regards to services gaps some of them have been referred in this paper as well. The competitive criteria are largely defined as "a consistent set of priorities that a company chooses to compete in its market place" (PAIVA et. al, 2004). Usually competitive criteria include cost, speed of delivery, quality, dependability and flexibility. Wheelwright (1984) identified that many researchers in operations management literature (NEW, 1992) treat dependability criterion as a symbol of confidence that the physical good or service product would operate according to the specifications.

For service, it is important to have the deliveries at the promised time and also to ensure that the problem is solved within the shortest time-span. (WHEELWRIGHT, 1984). There are always minor changes of this competitive criteria group as services sector itself is subjective. (HAYES; PISANO; 1996, PAIVA et al., 2004). Few researchers feel that time delivery should be treated as one of the most important criterion from competition view point instead of the dependency on the criterion. SERVQUAL model (PARASURAMAN ET AL., 1988) is a unique scale which identifies gaps in the service. There are five criteria recognized by the researchers, viz: tangibility, reliability, responsiveness, empathy and assurance. Fitzsimmons and Fitzsimmons suggested performance criteria as: availability, convenience, dependability, price, customization, quality, reputation, and security and last but not the least speed in 2020 .

Brooks mentioned in the International Maritime Transport in 1993 that service outcome is influenced by the interaction between the buyer and supplier that include communication, security, as well as the dependability. The similar factors were identified by Mentzer et al. (2003) regarding the implementation of the supply chain management. Interactions between the buyer-supplier is vital to the length of relationship and favorably impacts service outcomes. It shows a need for investments in employee qualification and also about upgrading the technology platform. Security as perceived by both buyer and seller and dependability also are important factors that enable relationship building and boost confidence. Few significant managerial decisions, such as why is it important to invest with respect to traceability based on information technology. In some of the cases it is observed that relationship continuity is negatively correlated with service performance when the service perceived took things for granted.

Relationship management related to Service outcome is very close to the traditional manufacturing supply chains. The parameters often used such as dependability, delivery and cost depend on managing the relationships. This involves transparency in the exchange of information and trust. According to Dyer and Nobeoka (2000), "the change is desired for a new mindset in service industry, which not only is related to the competitive approach but with a new thought process of relationship management".

\section{RESEARCH METHODOLOGY}

This paper is attempted by using secondary data involving summary, gathering and combination of published/ unpublished research. Various resources like national and internal research papers/articles, journals, relevant websites were observed in order to extract information for this paper. With the help of this research, the paper aims to study after-sales service, observe the service gaps in it, and finally arrive with practical discussion $\mathrm{Ct}$ recommendations.

After Sales Service: The producers and sellers of capital as well as consumer goods cannot assume that their job ends once the product/service is sold. They must realize that they need to provide a range of supporting after-sales services to their customers. The market for after-sales service in case of some industries is found to be four to five folds bigger, than the market for product sales, when observed from the economic perspective (Bundschuh and Dezvane, 2003). Similar finding were reported by Wise and Baumgartner (1999) and Alexander et al. (2002), who were of the opinion that after-sales service can provide more profit than product sales. In 2002, Rolls-Royce's aero-engines generated 50\% of its business revenues from the services provided. Lewis et al.(2004) came across similar observations in the elevator industry. In the context of competitive world market and lower profits generating from the sales of the product, after-sales service can constitute as an avenue of generating profit. It can be considered as a key differentiator for production houses. This has resulted in most of the manufacturing companies shifting their traditional approach of being a product-centric organization, to a customer-centric organization (Lele, 1997).

The Role of After-Sales Service: As stated by Gallagher et al. (2005), the executives who manage the aftersales \&t service businesses are very often not involved in the discussions and decisions regarding sales and product which affects the profit and the capacity to serve consumers. In order to evaluate "the total revenue 
that can be generated from the time when the original product is sold, till it is retired from the field, and thus to maximize profit opportunities, collaboration and close communication is important among after-sales, sales and product development teams". It also means the increase in the technical resources required for the after-sales function. Thus, the 'cross-functional communication' is very crucial to fully exploit the potential of aftersales. The receptiveness to evaluate the feedback and data received through after-sales is also vital, especially regarding the functions mentioned below:

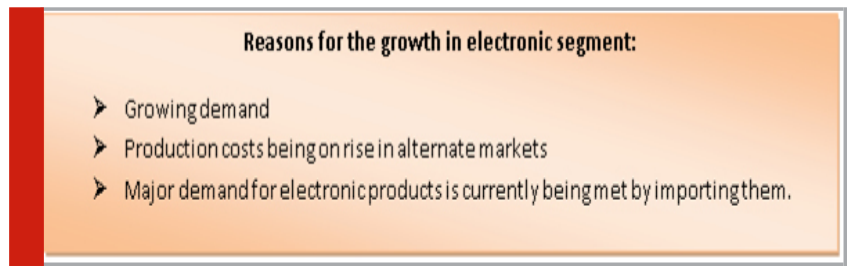

1. Development of a New Product and Redesigning of the existing product and/or process: Redesigning of a product and component as well as the development of new products can have its strong foundation in the reliable data that comes from the users. It is also useful for maintenance activities.

2. Sales: Data Analytics is being the new trend in the business world. Customer data can help in generating more sales and also in promotion activities.

3. Marketing: The information thus generated, is helpful for managing relations with the customers and can enhance the customer satisfaction which ultimately leads to customer lo.

Consumer electronics segment in India is vast, increasing and is majorly driven by imports.

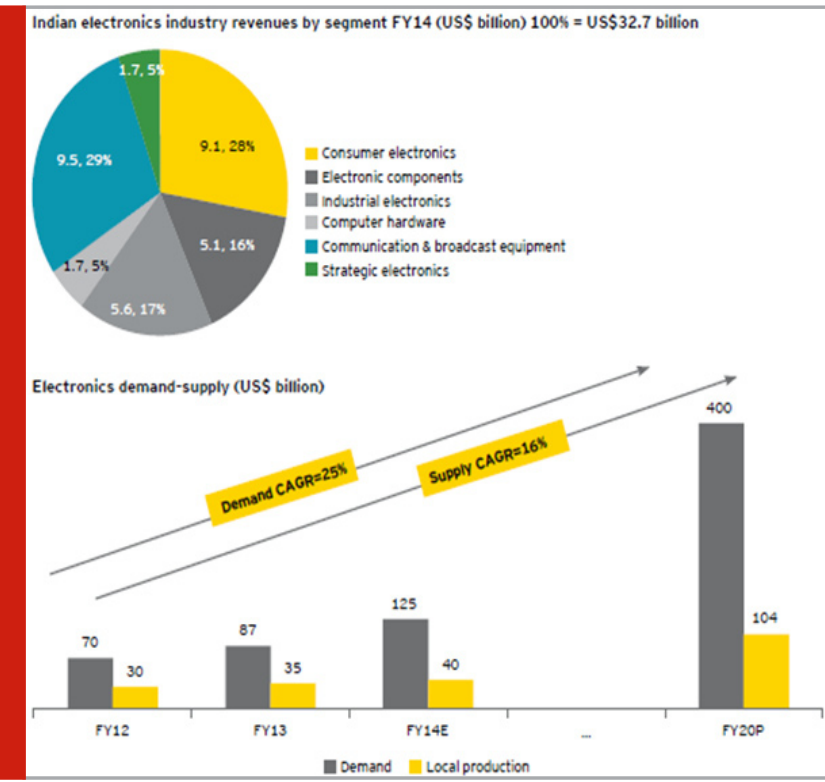

Note: Consumer electronics includes TVs, DVD players, MP3 players, digital cameras, and other household appliances.

Source: DeitY reports; MoC reports; Make in India website, http://makeinindia.com/sector/electronicsystems-design/, accessed 25 February 2015.

\section{Consumer durables market in India is traditionally a "high spend", priority sector}

More than 40\% of the end consumer spending in India comes from the consumer durables.

This sector contributes to more than 5.5\% of IIP.

For everyone direct job, it creates3 in-direct employment opportunities.

Import intensive sector and second top contributor to the current account deficit.

Major part of consumer durables comes from the urban market in India. However, in future the growth is expected to come in from the rural markets.

* The document refers to AC, washing machines and refrigerators as white goods.

\begin{tabular}{|c|c|}
\hline \multicolumn{2}{|c|}{ Consumer durables } \\
\hline Consumer appliances & Consumer electronics \\
\hline \multirow{2}{*}{$\begin{array}{l}\text { Air conditioners (AC) } \\
\text { Refrigerators } \\
\text { Washing machines }\end{array}$} & TVS \\
\hline & $\begin{array}{l}\text { Audio and video } \\
\text { systems }\end{array}$ \\
\hline \multirow{5}{*}{$\begin{array}{l}\text { - Sewing machines } \\
\text { - Electric fans } \\
\text { - Microaning equipment } \\
\text { - Other domestic } \\
\text { appliances }\end{array}$} & $\begin{array}{l}\text { Electronic } \\
\text { accessories }\end{array}$ \\
\hline & - CD and DVD players \\
\hline & - Digital cameras \\
\hline & - Camcorders \\
\hline & \\
\hline
\end{tabular}

The market for white goods* and televisions is on rise, but currently under-penetrated

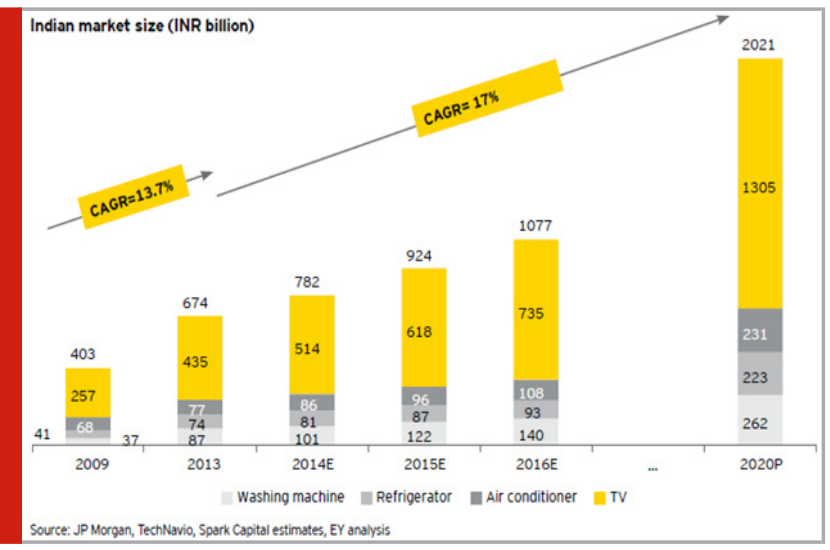

Service Supply Chain: Turning Potential into Profit: An increasing number of experts in the finance and 
production domains, are of the opinion that the potential for profit is more in the service business. However, transformation of this potential into profit, remains a challenge. A recent AMR Research study reports that though after-sales service, represents 24 percent of the total revenue, it creates 45 percent of the profit. Today products are getting commoditized, new products which are being manufactured have lesser margins and are getting harder to sell. This gives rise to opportunities to make profit through better customer service. After-sales service can be seen as a low-risk, long-term revenue model, especially for industries such as aerospace, where an approximate lifecycle of a product is around 25 to 30 years. Improved service quality will lead to enhanced customer satisfaction. This will increase new product sales. With growth in outsourcing and increased competition in manufacturing, efficient after-sales service can be seen as driving force to enhance customer value.

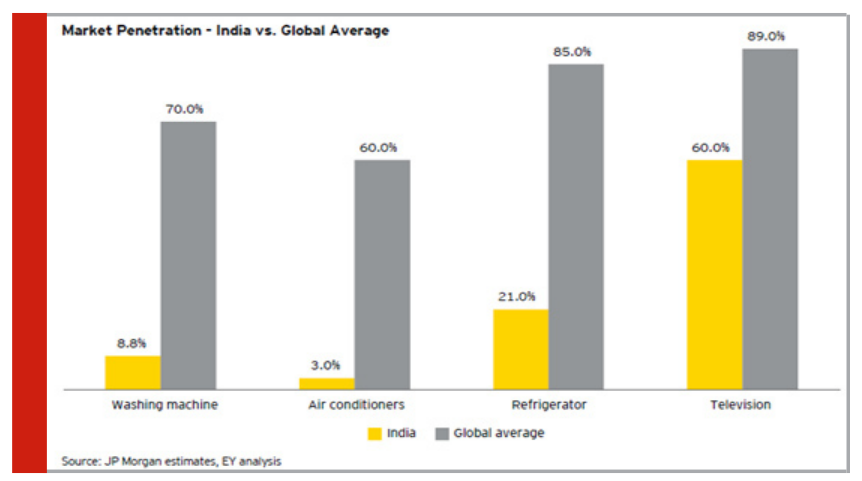

A Supply Chain's Unique Requirements: The service supply chain, often underestimated by most executives, is complex and involves field service, reverse logistics, network design and crucial inventory location decisions that are bonded with service level agreements (SLAs). This is not the case in case of the supply chain of a manufacturing unit.

The service supply chain is more complex than the manufacturing supply chain

Frequently, organizations use the same efficiencies of the outbound supply chain for a new product as well as the after-sales service parts. While existing operations must be leveraged for after-sales services \& support, they cannot be effective for handling the nuances of after sales activities. Companies must be prepared to deliver aggressive field service capabilities, depending upon the type of after-sales service supply chain they use. To fulfill the commitments related to services, aftersales service has to be more than merely reversing the processes being currently used. It has to be done in a systematic and exhaustive manner with special emphasis on Customer Centricity, Mean Time To Repair (MTTR), Uptime reduction and moving Downtime towards zero, by offering preventive maintenance and support service.
8. Customer Centricity: In the era where customer has become the most powerful element in the business ecosystem there is a need from the organizations to continuously evolve. Organizations cannot rest on their past laurels and become complacent. Companies will have to be high on customer centricity by continuously monitoring its activities around the customer. Companies will also have to understand the changing customer and be adaptable. The organizations which realize and are ready to create supply chains with this new insight, shall have a sustainable competitive edge, in the brutally aggressive market. In future, the companies that focus on customer service and after-sales support, will be successful. Customers are very conscious about the life of the product and are evaluating Total Cost of Ownership (TCO) of the product while making purchase decisions. It indicates that customer wants to enjoy their investment in the product for a long duration subject to product delivers all what is expected out of it. Provision should be made for upgrading the same product with minor modifications at the customer's site to help customer advance with time and technology. This will enhance the PLC of a product and will encourage the companies to increase their after-sales revenue and profits from the same customer, thereby reducing the cost of marketing and new customer acquisition.

9. After sales Service Gaps: It has been observed that poor performance of many organizations is due to lack of capabilities with respect to planning, managing, and monitoring the service business. Majority of the organizations can't predict the requirements of parts business. This results in inefficiency in managing customer expectation of after sales services, spare parts, and ability to serve the customer satisfactorily. Many organizations consider lack of supplier responsiveness and long lead times as the obstacles to service excellence. Many a times companies do not have the necessary capabilities to build profitable customer relations that deliver sustained customer satisfaction and of course customer loyalty. Formulation of the plan, its execution and its implementation are challenges as well.

Indian customer has been considerate to a large extent when it comes to after sales services but with the expectations of the customer increasing some of the obvious service gaps in after-sales services are as below:

- Capability Gap: This gap occurs when the growth of the company or growth of new product development is faster than anticipation and organization is unable to cope with the changes and occurs a capability gap. This could also result sometimes due to lack of a particular skill set in an organization. Lack of proficiency or sufficiency may be another reason due to which this gap is observed.

- Design Gap: Designing a service process especially in an environment where customer may become part of the process is extremely challenging. Design always requires a lot of vision and foresight. The most important part of the service design is the 
element of flexibility which is a requirement in the services sector.

- Response-delivery gap: Responding the customer at the click of the mouse is the expectation of the customer today. Thanks to technology a lot of things have been made possible especially in the financial sector. In case of after sales services response to customer call is the fundamental requirement. The challenge is not many service providers understand the value of this response. The delivery gap occurs because of the poor mindset of the services provider and also due to lack of planning at the execution stage in the services.

- New Product Development: Acquisition of new knowledge to repair/service the new product is always a challenge. Moreover, the increasing frequency of types/versions of a product adds to the challenge. Therefore this is another gap which can be taken care by continuous training on skill building and planning to train the services provider before the product is launched so that response time to customer is also reduced.

- Inventory \& Spares management: One of the most discussed topics in operations management is inventory. The more the product variety in the market the chances are more the inventory. Here inventory is all about the spares available throughout the distribution chain. It could be at services centres which again seems to be important from services point view.

- Tailored Services / Customization: Today's customers aren't just happy with standard products and services, but they are on lookout for new types of products which can help them reduce their pain points. In some of the categories, customer expect that down time should be as low as zero. With this ever increasing expectation of the customer of even customizing the product and services creates a lot of stress in the system and hence services failure gap occurs in the supply chain.
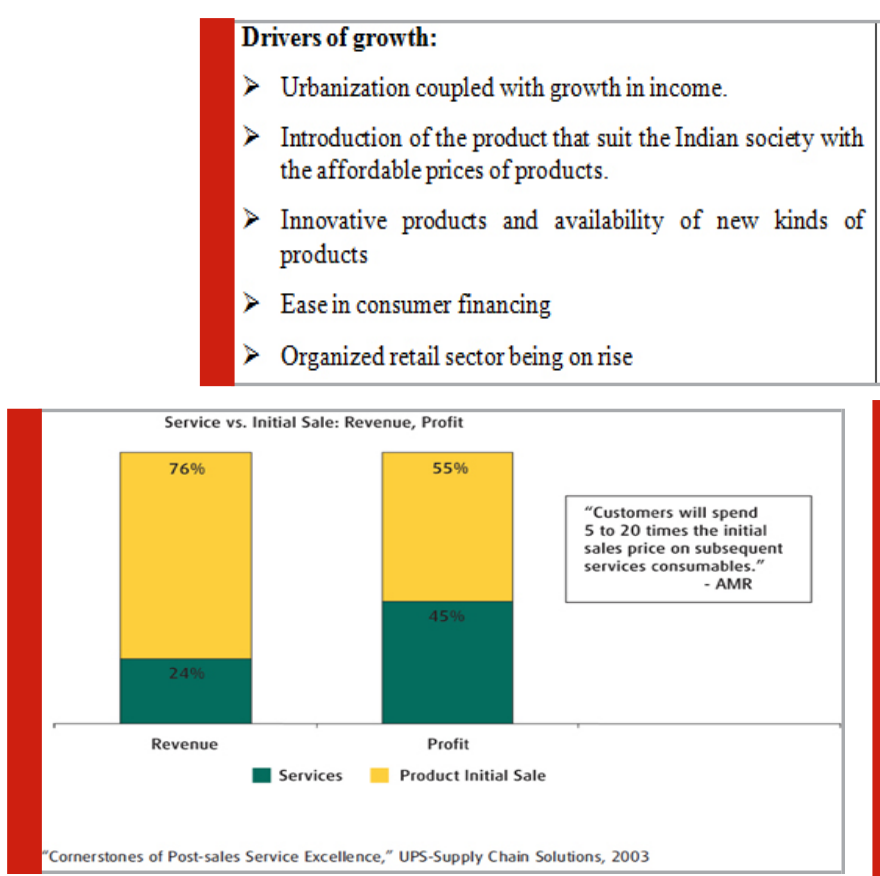

\section{DISCUSSION}

It is often seen that after sales services have been termed as a support system which is very important from customer perspective but not very important from organizational view. Service operations suffer due to two major factors, first one being the under-staffing and second one being the low investment. Today customers are as demanding about the after-sales service as they are about the products and services they purchase, even when the transaction takes place online. Though there is a growth in the customers' expectations with respect to after-sales service, it is observed that most of the times they are disappointed and get frustrated with the kind and quality of customer service they get. It has also been noted during the research that many

\section{Market penetration: \\ India is still a market that remains underpenetrated \\ Primary sales will be used for local consumption and market penetration as against the replacement sales, that dominates the urban markets. \\ Key to success will be reduced total cost of ownership.}

The service supply chain is more complex than the manufacturing supply chain

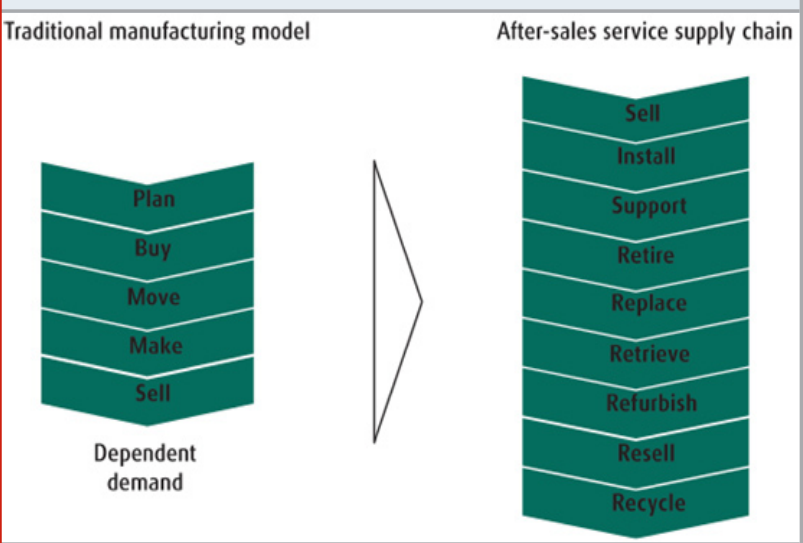

companies do not keep the track of their customer once the customer's query is resolved by their call centre. Services providers have a great opportunity to earn from warranty cost which is built in the system that are borne by the company for attending calls for products under warranty. Income from repairing stocks at dealers and distributors, usually repairs due to transit damages, is another source of income. Service department can also earn through servicing products and services which are out-of-warranty through chargeable calls and annual maintenance contracts. 
In manufacturing sector supply chain has seen a large percent of the IT investments while only a small percent has been applied to customer annuity. The customer annuity supply chain is substantially more complex, but the after-sales service markets represent enormous opportunity for services business providers. There is a clear opportunity for all the companies in general and manufacturers in particular, to capture lost profits and positively create an annuity stream of revenue from customers.

The barriers should be overcome and there is a need to create a suitable culture where people have a complete understanding of the supply chain, and a framework to follow for execution. The manufacturer that focuses on customer annuity should build loyalty that supports the rapid product lifecycle changes created by technology. The company that has the potential to adapt the current situation can implement an effective customer annuity program. This will help receive rewarded with increased profits and a definite competitive advantage that will be hard for others to duplicate.

Recommendation: As we are aware that technology has taken into grip all the sectors of the industries and after sales service supply chain cannot be far away from deploying technology to improve the overall efficiency of the after sales services. Focus on capability management, improving service attitude of the services provider, investing in services process design, understanding of tangibility and intangibility elements in services are some of the most important areas where one needs to look into, for improving service supply chain. It is also recommended to align the service and support performance with today's online consumer behavior. It is suggested that one of the ways to enhance the service experience is to open newer service channels.

Social media and other technology tools should be used to be close to the customer. Internet of everything (IOE) which talks about artificial intelligence could be utilized to enhance experience of the customers. Machine-to-machine connectivity through Bluetooth devices and inexpensive sensors have helped improve servicing the customer better. Service operations must build "digital-relevant" speed and agility to be in line with digital consumer of today. This would be the way in which organizations can deliver the enhanced aftersales service experience that will be fondly remembered by the customers and would help in generating customer loyalty.

\section{REFERENCES}

Berry, L.L. and Parasuraman, A. (1991), Marketing Services: Competing through Quality, Free Press, New York, NY

Birgelen M. Van, Ruyter J.C. de, Jong A. de and Wetzels M.G.M. 2002. Customer evaluations of aftersales service contact modes: An empirical analysis of national culture's consequences. International Journal of Research in Marketing. Vol. 19, No. 1, pp.43-64.

Boshoff C. and Gray. B. 2004. The relationships between service quality, customer satisfaction and buying intentions in the private hospital industry. South African Journal of Business Management. Vol. 35, No. 4, pp. 27-37.

Bundschuh, R.G., Dezvane, T.M., 2003. How to make after sale services pay off. The McKinsey Quarterly (4), 116-127

Dyer, Jeffrey H. and Kentaro Nobeoka. 2000. “Creating and Managing a High-Performance Knowledge-Sharing Network: The Toyota Case." Strategic Management Journal 21: 345-367

Erasmu A.C., Boshoff E. and Rousseau G.G. 2001. Consumer decision-making models within the discipline of consumer science: a critical approach. Journal of Family Ecology and Consumer Sciences. Vol. 29, pp. 82-90.

Fitzsimmons, J.A., Fitzsimmons, M., 2000. New Service Development - Creating Memorable Experiences. Sage Publications, Thousand Oaks, CA

Gaiardelli P., Saccani N. and Songini L. 2007. Performance measurement systems in after-sales service: an integrated framework. International Journal of Business Performance Management. Vol. 9, No. 2, pp. 145-171.

Gallagher, T.; Mitchke, M. D.; Rogers, M. C. (2005). Profiting from spare parts. The McKinsey Quarterly, Web exclusive.

Hayes, R.H. and Pisano, G.P. (1996), "Manufacturing strategy: at the intersection of two paradigm shifts", Production and Operations Management, Vol. 5, No. 1, pp. 25-41

Julie Drzymalski, Supply Chain Frameworks for the Service Industry: A Review of the Literature European International Journal of Science and Technology Vol. 1 _o. 3 December 2012

Lele, M. (1997). After-sales service: Necessary evil or strategic opportunity? Managing Service Quality, 7(3), 141-145

Levitt, T. (1983), “The Globalisation of Markets”, Harvard Business Review May/Jun. Cited in de Wit, B \& Meyer, R, (1998), "Strategy Process, Content Context, an International Perspective" 2nd Ed, West. Pp 733-741

Mentzer, J.T., deWitt, W., Keebler, J.S., and Min, S. (2001). Defining supply chain Management. Journal of Business Logistics, 22 (2), 1-25.

Sakun Boonitt and Chanida Pongpanarat Measuring Service Supply Chain Management Processes: The 
Application of the Q-Sort Technique International Journal of Innovation, Management and Technology, Vol. 2, No. 3, June 2011

Slack, N., Chambers, S. and Johnston R. (2004). Operations Management (4th Edition), Harlow: Pearson Education.

Verma, R., Thompson, G. M., \&t Louviere, J. J. (1999).
Configuring service operations in accordance with customer needs and preferences

Wheelwright, S.C., (1984). Manufacturing strategy: Defining the missing link. Strategic Management Journal. 5 (1): 77-91

Wise, R. and Baumgartner, P. (1999), 'aGo downstream: the new imperative in manufacturing ${ }^{\circ}$, Harvard Business Review, Vol. 77 No. 5, pp. 133-41. 